\title{
Study on Growth and Yield of Upland Terrace Rice as Affected by Different Levels of Nitrogen and Spacing in Kiphire District, Nagaland of NE India
}

\author{
N. Khumdemo Ezung* and Tiatula Jamir \\ ${ }^{1}$ ICAR Research Complex for NEH Region, Nagaland Centre, Medziphema, \\ Nagaland-797106, India \\ ${ }^{2}$ Agriculture Technology Management Agency, Wokha, Government of Nagaland, Department \\ of Agriculture, Wokha-797111, Nagaland, India \\ *Corresponding author
}

\section{A B S T R A C T}

Keywords

Upland terrace rice, Nitrogen, Spacing, Growth, Yield, Economics

Article Info

Accepted:

07 June 2019

Available Online:

10 July 2019
An experiment was conducted at KVK, Kiphire experimental farm during kharif season of the year 2018 to assess the influence of different nitrogen levels and spacing on growth and yield of upland terrace rice. The experiment was laid out in RBD and conducted in factorial experiment with three replications. The experiment revealed that application of $90 \mathrm{~kg} \mathrm{~N} / \mathrm{ha}$ recorded the highest grain yield $(52.55 \mathrm{q} / \mathrm{ha})$ and $20 \times 10 \mathrm{~cm}$ spacing recorded the highest grain yield $(45.65 \mathrm{q} / \mathrm{ha})$. The treatment interaction effect also resulted in similar trend where application of $90 \mathrm{~kg} \mathrm{~N} / \mathrm{ha}$ and $20 \times 10 \mathrm{~cm}$ interaction resulted the highest grain yield $(52.00 \mathrm{q} / \mathrm{ha})$. The economic analysis revealed that the combination with the application of 90 $\mathrm{kg} \mathrm{N} / \mathrm{ha}$ and $20 \times 10 \mathrm{~cm}$ spacing resulted in the highest economic return which recorded a $\mathrm{B}$ : $\mathrm{C}$ ratio of 3.68 .

\section{Introduction}

Rice is the staple food for the people of Kiphire, Nagaland and grown mostly in hilly slopes as direct seeded upland rice under rainfed condition. The major crops grown are paddy, maize, potato, kholar and soyabean. The gross cropped area accounts for 48.55 ('000 ha) which is mostly under Jhum. The production and productivity of rice was recorded at 14.23 ('000 t) and $17.14 \mathrm{q} / \mathrm{ha}$ which is very low for meeting the need of the population. With the increase in population, limited land resources and insufficient rice crop production in Nagaland, it is likely to pose a serious problem of food shortage $n$ the days to come. The main factor leading to low crop production in Kiphire may be due to farmers' adoption of traditional cultivation practices (Jhum). There is almost zero 
utilization of farm inputs including chemical fertilizers and pesticides and the seed are sown at random without any definite row arrangement. All these unscientific practices ultimately lead to reduce crop yield. Among several agronomic approaches for rice, spacing and fertilizer nitrogen application remains the most important factor affecting the growth and yield of rice. Thus, the present investigation was carried out to standardize the optimum nitrogen levels and spacing for upland rice condition in Kiphire, District, Nagaland.

\section{Materials and Methods}

The experiment was carried out in the experimental farm of KVK, Kiphire, ICAR for $\mathrm{NEH}$ Region, Nagaland Centre during the kharif season during the year 2018. The experimental farm is located at an altitude of 896.42 MSL with humid and hot during summer and cold during winter with winter temperature touching a low of $2.7^{\circ} \mathrm{C}$ and a high of $37.0^{\circ} \mathrm{C}$ during summer. Monsoon period extends from June to September and sometimes up to October. The average rain fall for the last three years is $876 \mathrm{~mm}$. Undulating topography with sandy loam to fine rich humus soil constitutes the main soil condition.

The experiment was laid out in "Randomised Block Design" and conducted in "Factorial Experiment" (2 levels of factors) with three replications. The dose of nitrogen was $30 \mathrm{~kg}$ $\mathrm{N} / \mathrm{ha}\left(\mathrm{N}_{1}\right), 60 \mathrm{~kg} \mathrm{~N} / \mathrm{ha}\left(\mathrm{N}_{2}\right)$ and $90 \mathrm{~kg} \mathrm{~N} / \mathrm{ha}$ $\left(\mathrm{N}_{3}\right)$ with $0 \mathrm{~kg} \mathrm{~N} / \mathrm{ha}\left(\mathrm{N}_{0}\right)$ as check and was applied through urea. The spacing was at $10 \times 10 \mathrm{~cm}\left(\mathrm{~S}_{1}\right), 20 \times 10 \mathrm{~cm}\left(\mathrm{~S}_{2}\right)$ and $30 \times 10 \mathrm{~cm}$ $\left(\mathrm{S}_{3}\right)$. A uniform recommended dose of $\mathrm{P}_{2} \mathrm{O}_{5}$ and $\mathrm{K}_{2} \mathrm{O}$ was applied as basal. Half dose of nitrogen through urea was applied as basal and the remaining was applied in two equal split dose, one at active tillering and the other at panicle initiation stage.

\section{Results and Discussions}

\section{Growth attributes}

\section{Plant height (cm)}

The higher of plant was significantly increased by application of different levels of nitrogen at $30,60,90,120$ DAS and at harvest where the maximum plant height $(\mathrm{cm})$ was recorded at 120 DAS with the application of $90 \mathrm{~kg} \mathrm{~N} / \mathrm{ha}$ which was however, found to be at par with the application of $60 \mathrm{~kg} \mathrm{~N} / \mathrm{ha}$ (Table 1a). A similar finding was also reported by Geethadevi et al., (2000).

The maximum plant height was recorded at harvest which was from $30 \times 10 \mathrm{~cm}$ and was found to be at par with $20 \times 10 \mathrm{~cm}$. Ninad et al., (2017) also reported similar finding.

The treatment interactions reveals that the maximum plant height was recorded from the combination of $90 \mathrm{~kg}$ N/ha with $30 \times 10 \mathrm{~cm}$ spacing at all the growth stages which was however, found to be at par with $60 \mathrm{~kg} \mathrm{~N} / \mathrm{ha}$ and 20x10 cm spacing (Table $1 \mathrm{~b}$ ). This may be due to well-developed roots and less competition for nutrients and moisture among the plants.

\section{Number of effective tillers/hill}

The number of effective tillers per hill was significantly increased with increasing the levels of nitrogen.

The data revealed that the maximum number of effective tillers per hill was recorded from the application of $90 \mathrm{~kg} \mathrm{~N} / \mathrm{ha}$ (Table 2a).

Similar observation was also reported by Lawal and Lawal (2002) and Shrirame et al., (2000). No significant effect due to spacing was observed on the number of effective tillers/hill. 


\section{Yield attributes}

\section{Panicle length $(\mathrm{cm})$}

The result revealed that with the application of $90 \mathrm{~kg} \mathrm{~N} / \mathrm{ha}$ resulted in the highest panicle length as compared with the rest of the treatments (Table 2a). This finding finds conformity with the finding of Bindra et al., (2000) who reported that application of $90 \mathrm{~kg}$ $\mathrm{N} / \mathrm{ha}$ recorded the highest panicle length (30.7 $\mathrm{cm})$. The highest panicle length was recorded from a spacing of $20 \times 10 \mathrm{~cm}(24.92 \mathrm{~cm})$ which was at par with $30 \mathrm{x} 10 \mathrm{~cm}$ spacing $(24.11 \mathrm{~cm})$ (Table 1a). The treatment interaction revealed that the maximum panicle length was recorded at $27.33 \mathrm{~cm}$ with the application of $90 \mathrm{~kg} \mathrm{~N} / \mathrm{ha}$ and $30 \times 10 \mathrm{~cm}$ spacing which was however, found to be at par with the application of 60 $\mathrm{kg} \mathrm{N} / \mathrm{ha}$ with $30 \times 10 \mathrm{~cm}$ and $90 \mathrm{~kg} \mathrm{~N} / \mathrm{ha}$ with the rest of the spacing (Table $2 b$ ).

\section{Number of grains per panicle}

The treatment effect on the number of grains per panicle revealed that application of $90 \mathrm{~kg}$
$\mathrm{N} /$ ha recorded the highest number of grains per panicle (167.27) (Table 2a). The maximum number of grains/panicle was recorded with $20 \times 10 \mathrm{~cm}$ which was found to be at par with 30x10 cm (Table 2a). Similar finding was also reported by Bhowmik et al., (2012).

The treatment interaction effect reveals that application of $90 \mathrm{~kg} \mathrm{~N} / \mathrm{ha}$ and $20 \times 10 \mathrm{~cm}$ spacing significantly recorded the highest number of grains per panicle (Table 2b).

\section{Test weight $(g)$}

The effect of nitrogen levels was found to significantly affect the test weight which resulted in highest test weight being recorded from the application of $90 \mathrm{~kg} \mathrm{~N} / \mathrm{ha}(31.67 \mathrm{~g})$ (Table 2a).

Similar finding was also reported by Bindra $e t$ al., (2000) who reported that application of 90 $\mathrm{kg} \mathrm{N} / \mathrm{ha}$ resulted in the highest test weight of rice. No significant treatment effect was recorded from the spacing on the test weight.

Table.1 (a) Effect of nitrogen levels and spacing on plant height $(\mathrm{cm})$

\begin{tabular}{|c|c|c|c|c|c|}
\hline Treatments & \multicolumn{5}{|c|}{ Days after sowing } \\
\hline Nitrogen (kg/ha) & 30 & 60 & 90 & 120 & At harvest \\
\hline Control & 28.41 & 92.66 & 117.84 & 142.15 & 142.60 \\
\hline 30 & 28.49 & 96.64 & 121.66 & 145.42 & 145.91 \\
\hline 60 & 29.00 & 97.50 & 126.91 & 149.67 & 149.92 \\
\hline 90 & 29.83 & 102.24 & 127.08 & 151.42 & 151.86 \\
\hline $\operatorname{SEm}( \pm)$ & 0.04 & 1.31 & 0.92 & 1.05 & 0.89 \\
\hline $\mathrm{CD}(\mathrm{P}=0.05)$ & 1.24 & 3.86 & 2.71 & 3.08 & 2.61 \\
\hline \multicolumn{6}{|l|}{ Spacing (cm) } \\
\hline $10 \times 10$ & 28.11 & 96.30 & 122.01 & 146.03 & 146.53 \\
\hline $20 \times 10$ & 29.05 & 97.72 & 122.61 & 147.76 & 147.98 \\
\hline $30 \times 10$ & 29.63 & 97.75 & 125.50 & 147.70 & 148.20 \\
\hline $\operatorname{SEm}( \pm)$ & 0.40 & 1.14 & 0.80 & 0.91 & 0.77 \\
\hline $\mathrm{CD}(\mathrm{P}=0.05)$ & 1.17 & 3.35 & 2.34 & NS & NS \\
\hline
\end{tabular}


Int.J.Curr.Microbiol.App.Sci (2019) 8(7): 467-474

Table.1 (b) Interaction effect of nitrogen levels and spacing on plant height $(\mathrm{cm})$

\begin{tabular}{|c|c|c|c|c|c|}
\hline \multirow[t]{2}{*}{ Treatments } & \multicolumn{5}{|c|}{ Days after sowing } \\
\hline & 30 & 60 & 90 & 120 & At harvest \\
\hline $\mathbf{N}_{0} \mathbf{S}_{(10 \times 10)}$ & 27.70 & 89.80 & 116.86 & 142.00 & 142.66 \\
\hline $\mathbf{N}_{0} \mathbf{S}_{(20 \times 10)}$ & 27.75 & 92.86 & 117.80 & 143.73 & 142.13 \\
\hline $\mathbf{N}_{0} \mathbf{S}_{(30 \times 10)}$ & 28.00 & 93.73 & 118.86 & 144.13 & 144.00 \\
\hline $\mathbf{N}_{30} \mathbf{S}_{(10 \times 10)}$ & 28.38 & 94.93 & 119.66 & 144.73 & 145.73 \\
\hline $\mathbf{N}_{30} \mathbf{S}_{(20 \times 10)}$ & 28.40 & 95.33 & 120.40 & 144.53 & 147.06 \\
\hline $\mathbf{N}_{30} \mathbf{S}_{(30 \times 10)}$ & 28.66 & 96.60 & 124.53 & 146.46 & 144.93 \\
\hline $\mathbf{N}_{60} \mathbf{S}_{(10 \times 10)}$ & 28.79 & 97.53 & 124.93 & 147.00 & 146.86 \\
\hline $\mathbf{N}_{60} \mathbf{S}_{(20 \times 10)}$ & 28.94 & 98.63 & 125.33 & 147.63 & 150.06 \\
\hline $\mathbf{N}_{60} \mathbf{S}_{(30 \times 10)}$ & 29.33 & 100.96 & 126.13 & 149.80 & 147.83 \\
\hline $\mathbf{N}_{90} \mathbf{S}_{(10 \times 10)}$ & 30.00 & 101.00 & 127.80 & 151.60 & 151.86 \\
\hline $\mathbf{N}_{90} \mathbf{S}_{(20 \times 10)}$ & 30.66 & 102.95 & 128.93 & 152.26 & 152.66 \\
\hline $\mathbf{N}_{90} \mathbf{S}_{(30 \times 10)}$ & 32.83 & 103.78 & 129.26 & 155.53 & 156.06 \\
\hline $\operatorname{SEm}( \pm)$ & 0.80 & 2.28 & 1.60 & 1.80 & 1.54 \\
\hline $\mathrm{CD}(\mathrm{P}=\mathbf{0 . 0 5})$ & 2.15 & 6.70 & NS & 5.34 & 4.53 \\
\hline
\end{tabular}

Table.2 (a) Effect of nitrogen levels and spacing on number of effective tillers/hill, panicle length $(\mathrm{cm})$ and number of grains/panicle

\begin{tabular}{|c|c|c|c|}
\hline Treatments & No. of effective tillers & Panicle length (cm) & $\begin{array}{c}\text { No. of } \\
\text { grains/panicle }\end{array}$ \\
\hline \multicolumn{4}{|l|}{ Nitrogen (kg/ha) } \\
\hline Control & 6.55 & 22.32 & 118.54 \\
\hline 30 & 5.57 & 23.58 & 134.47 \\
\hline 60 & 7.60 & 24.76 & 154.28 \\
\hline 90 & 7.80 & 26.41 & 167.27 \\
\hline $\operatorname{SEm}( \pm)$ & 0.35 & 0.37 & 2.30 \\
\hline $\mathrm{CD}(\mathrm{P}=\mathbf{0 . 0 5})$ & 1.05 & 1.10 & 6.76 \\
\hline \multicolumn{4}{|l|}{ Spacing (cm) } \\
\hline $10 \times 10$ & 7.06 & 23.77 & 137.49 \\
\hline $20 \times 10$ & 7.05 & 24.92 & 148.47 \\
\hline $30 \times 10$ & 7.30 & 24.11 & 144.96 \\
\hline $\operatorname{SEm}( \pm)$ & 0.31 & 0.32 & 1.99 \\
\hline $\mathrm{CD}(\mathrm{P}=\mathbf{0 . 0 5})$ & NS & 0.90 & 5.85 \\
\hline
\end{tabular}


Table.2 (b) Interaction effect of nitrogen levels and spacing on number of effective tillers/hill, panicle length $(\mathrm{cm})$ and number of grains/panicle

\begin{tabular}{|c|c|c|c|}
\hline Treatments & No. of effective tillers & Panicle length $(\mathrm{cm})$ & $\begin{array}{c}\text { No. of } \\
\text { grains/panicle }\end{array}$ \\
\hline $\mathbf{N}_{0} \mathbf{S}_{(\mathbf{1 0 x 1 0 )}}$ & 6.13 & 21.83 & 114.09 \\
\hline $\mathbf{N}_{0} S_{(20 \times 10)}$ & 7.26 & 22.07 & 120.52 \\
\hline $\mathbf{N}_{0} \mathbf{S}_{(30 \times 10)}$ & 6.26 & 23.08 & 121.00 \\
\hline $\mathbf{N}_{30} S_{(10 \times 10)}$ & 6.60 & 24.90 & 130.05 \\
\hline $\mathbf{N}_{30} \mathbf{S}_{(20 \times 10)}$ & 6.66 & 23.08 & 138.36 \\
\hline $\mathbf{N}_{30} S_{(30 \times 10)}$ & 6.46 & 22.76 & 135.00 \\
\hline $\mathbf{N}_{60} S_{(10 \times 10)}$ & 7.46 & 22.72 & 143.51 \\
\hline $\mathrm{N}_{60} \mathrm{~S}_{(20 \times 10)}$ & 7.46 & 24.24 & 158.33 \\
\hline $\mathrm{N}_{60} \mathrm{~S}_{(30 \times 10)}$ & 8.60 & 26.38 & 161.00 \\
\hline $\mathbf{N}_{90} \mathbf{S}_{(10 \times 10)}$ & 8.06 & 25.63 & 162.29 \\
\hline $\mathbf{N}_{90} \mathbf{S}_{(20 \times 10)}$ & 7.53 & 27.23 & 176.66 \\
\hline $\mathbf{N}_{90} S_{(30 \times 10)}$ & 7.86 & 27.33 & 162.86 \\
\hline $\operatorname{SEm}( \pm)$ & 0.62 & 0.65 & 3.99 \\
\hline $\mathrm{CD}(\mathrm{P}=0.05)$ & NS & 1.91 & 11.71 \\
\hline
\end{tabular}

Table.3 (a) Effect of nitrogen levels and spacing on test weight (g), grain yield (q/ha) and straw yield (q/ha)

\begin{tabular}{|c|c|c|c|}
\hline Treatments & Test weight (g) & Grain yield (q/ha) & Straw yield (q/ha) \\
\hline \multicolumn{4}{|l|}{ Nitrogen (kg/ha) } \\
\hline Control & 27.37 & 30.67 & 24.96 \\
\hline 30 & 28.10 & 44.59 & 29.46 \\
\hline 60 & 29.63 & 48.53 & 36.06 \\
\hline 90 & 31.07 & 52.55 & 42.61 \\
\hline $\operatorname{SEm}( \pm)$ & 0.61 & 0.51 & 1.73 \\
\hline $\mathrm{CD}(\mathrm{P}=\mathbf{0 . 0 5})$ & 1.81 & 1.51 & 5.08 \\
\hline \multicolumn{4}{|l|}{ Spacing (cm) } \\
\hline $10 \times 10$ & 28.36 & 40.53 & 29.60 \\
\hline $20 \times 10$ & 28.69 & 45.65 & 32.86 \\
\hline $30 \times 10$ & 30.08 & 45.57 & 37.36 \\
\hline $\operatorname{SEm}( \pm)$ & 0.53 & 0.44 & 1.50 \\
\hline $\mathrm{CD}(\mathbf{P}=\mathbf{0 . 0 5})$ & NS & 1.30 & 4.40 \\
\hline
\end{tabular}


Table.3 (b) Interaction effect of nitrogen levels and spacing on test weight (g), grain yield (q/ha) and straw yield (q/ha)

\begin{tabular}{|c|c|c|c|}
\hline Treatments & Test weight (g) & Grain yield (q/ha) & Straw yield (q/ha) \\
\hline $\mathbf{N}_{0} S_{(10 \times 10)}$ & 26.56 & 20.79 & 22.06 \\
\hline $\mathbf{N}_{0} \mathbf{S}_{(20 \times 10)}$ & 27.03 & 26.85 & 25.59 \\
\hline $\mathbf{N}_{0} S_{(30 \times 10)}$ & 28.53 & 28.37 & 27.25 \\
\hline $\mathbf{N}_{30} S_{(10 \times 10)}$ & 28.66 & 35.37 & 28.81 \\
\hline $\mathbf{N}_{30} \mathbf{S}_{(20 \times 10)}$ & 26.58 & 36.74 & 27.77 \\
\hline $\mathbf{N}_{30} S_{(30 \times 10)}$ & 29.06 & 38.67 & 31.81 \\
\hline $\mathbf{N}_{60} S_{(10 \times 10)}$ & 27.46 & 38.67 & 32.72 \\
\hline $\mathbf{N}_{60} S_{(20 \times 10)}$ & 29.70 & 41.03 & 32.54 \\
\hline $\mathbf{N}_{60} S_{(30 \times 10)}$ & 31.73 & 40.90 & 42.93 \\
\hline $\mathbf{N}_{90} \mathbf{S}_{(10 \times 10)}$ & 30.76 & 48.28 & 34.82 \\
\hline $\mathbf{N}_{90} \mathbf{S}_{(20 \times 10)}$ & 31.46 & 52.00 & 45.54 \\
\hline $\mathbf{N}_{90} S_{(30 \times 10)}$ & 31.00 & 49.37 & 47.47 \\
\hline $\operatorname{SEm}( \pm)$ & 1.06 & 0.89 & 3.00 \\
\hline $\mathrm{CD}(\mathrm{P}=\mathbf{0 . 0 5})$ & NS & 2.61 & NS \\
\hline
\end{tabular}

Table.4 Economics of rice cultivation as affected by different treatment combinations

\begin{tabular}{|c|c|c|c|c|}
\hline Treatments & Cost of cultivation & Gross return (Rs.) & Net return (Rs.) & B: C ratio \\
\hline $\mathbf{N}_{\mathbf{0}} \mathbf{S}_{(\mathbf{1 0 x 1 0})}$ & 14000 & 37422 & 23422 & 1.67 \\
\hline $\mathbf{N}_{\mathbf{0}} \mathbf{S}_{(\mathbf{2 0 x 1 0}}$ & 14000 & 48330 & 34330 & 2.45 \\
\hline $\mathbf{N}_{\mathbf{0}} \mathbf{S}_{(\mathbf{3 0 x 1 0}}$ & 14000 & 51066 & 37066 & 2.65 \\
\hline $\mathbf{N}_{\mathbf{3 0}} \mathbf{S}_{(\mathbf{1 0 x 1 0})}$ & 16000 & 63666 & 47666 & 2.98 \\
\hline $\mathbf{N}_{\mathbf{3 0}} \mathbf{S}_{(\mathbf{2 0 x 1 0}}$ & 16000 & 66132 & 50132 & 3.13 \\
\hline $\mathbf{N}_{\mathbf{3 0}} \mathbf{S}_{(\mathbf{3 0 x 1 0}}$ & 16000 & 69606 & 53606 & 3.35 \\
\hline $\mathbf{N}_{\mathbf{6 0}} \mathbf{S}_{(\mathbf{1 0 x 1 0}}$ & 18000 & 69606 & 51606 & 2.87 \\
\hline $\mathbf{N}_{\mathbf{6 0}} \mathbf{S}_{(\mathbf{2 0 x 1 0}}$ & 18000 & 73854 & 55854 & 3.10 \\
\hline $\mathbf{N}_{\mathbf{6 0}} \mathbf{S}_{(\mathbf{3 0 x 1 0}}$ & 18000 & 73620 & 55620 & 3.09 \\
\hline $\mathbf{N}_{\mathbf{9 0}} \mathbf{S}_{(\mathbf{1 0 x 1 0}}$ & 20000 & 86904 & 66904 & 3.35 \\
\hline $\mathbf{N}_{\mathbf{9 0}} \mathbf{S}_{(\mathbf{2 0 x 1 0}}$ & 20000 & 93600 & 73600 & 3.68 \\
\hline $\mathbf{N}_{\mathbf{9 0}} \mathbf{S}_{(\mathbf{3 0 x 1 0}}$ & 20000 & 88866 & 68866 & 3.44 \\
\hline
\end{tabular}

\section{Grain yield (q/ha)}

It was observed that the grain yield increased with the increase of nitrogen levels thus recording the highest grain yield from the application of $90 \mathrm{~kg} \mathrm{~N} / \mathrm{ha}$ which was recorded at $52.55 \mathrm{q} /$ ha (Table $3 \mathrm{a}$ ). This might be due to better uptake of nitrogen leading to greater dry matter production and its translocation to sink. Similar finding was also reported by Bindra et al., (2000) who found that application of $90 \mathrm{~kg} \mathrm{~N} / \mathrm{ha}$ resulted in the highest grain yield. The maximum grain yield (45.65 q/ha) was recorded from 20x10 cm 
which was observed to be at par with $30 \times 10$ $\mathrm{cm}$ (Table 3a). This might be due to higher ear bearing tillers per unit area as compared to $30 \times 10 \mathrm{~cm}$. This finding finds similarity with the finding reported by Geethadevi et al., (2000) and Ninad et al., 2017, who reported that the highest grain yield was recorded from $20 \times 10 \mathrm{~cm}$ spacing. The interaction effect reveals that application of $90 \mathrm{~kg} \mathrm{~N} / \mathrm{ha}$ with $20 \times 10 \mathrm{~cm}$ spacing recorded the significantly the highest grain yield (52 q/ha) as compared with the rest of the treatment combination (Table 3b).

\section{Straw yield (q/ha)}

With the increase in levels of nitrogen, the straw yield also tends to increase with the highest being recorded from the application of $90 \mathrm{~kg} \mathrm{~N} / \mathrm{ha}$ (Table 3a) as compared with the rest of the treatments which finds conformity with the findings reported by Rajendran and Veeraputhiran (1999). The maximum straw yield was recorded from 30x10 cm spacing which may be due to better utilization of resources.

\section{Economic analysis}

The economics for the different treatment were worked out in order to enable us to decide the suitable treatment combinations for profitable rice cultivation.

Among the different treatment combinations, the maximum net return was recorded from the application of $90 \mathrm{~kg} \mathrm{~N} / \mathrm{ha}$ and $20 \times 10 \mathrm{~cm}$ spacing (Rs.73600) recording the highest B: C ratio at 3.68 (Table 4$)$.

On the basis of the above findings, it can be concluded that application of $90 \mathrm{~kg} \mathrm{~N} / \mathrm{ha}$ with a spacing of $20 \times 10 \mathrm{~cm}$ which resulted in highest grain yield and economic return may be considered for adoption by the farmers of Kiphire, District.

\section{References}

Bhowmik. K., Sarkar M. A. R and Zaman F. 2012. Effect of spacing and number of seedlings per hill on the performance of aus rice cv. NERICA 1 under dry direct seeded rice (DDSR) system of cultivation S. Journal of Bangladesh Agricultural University. 10(2): 191-195.

Bindra, A.D., Kalia, B.D., Kumar, S.2000. Effect of graded levels of nitrogen and dates of transplanting on growth and yield attributes of scented rice. Advances in Agricultural Research in India. 10: 45-48.

Geethadevi, T., Andani Gowda, Krishnappa, M/ and Babu, B.T.R. 2000. Effect of nitrogen and spacing on growth and yield of hybrid rice. Current Research. 29 (56):73-75

Lawal, M.I. and Lawal, A.B. 2002. Influence of nitrogen rate and placement method on growth and yield of rice (Oryza sativa. L) at Kadawa, Nigeria. Crop Research (Hissar). 23 (3): 403-411.

Ninad T. A., Bahadur, M. M., Hasan, M. A., Alam, M. M. and Rana M. S. 2017. Effect of spacing and seedling per hill on the effect of spacing and seedling per hill on the effect of spacing and seedling per hill on the effect of spacing and seedling per hill on the performance of aus rice performance of aus rice performance of aus rice performance of aus rice var. BRRI dhan48. Bangladesh Agron. J. 2017, 20(2): 17-26.

Rajendran, K. and Veeraputhiran, r. 1999. Effect of seed rate and nitrogen levels on hybrid rice (Oryza sativa). Madras Agricultural Journal. 86(7-9): 459-460.

Shrirame, M.D., Rajgire, H.J. and Rajgire, A.H. 2000. Effect of spacing and seedling number per hill on growth attribute and yield of rice hybrids under lowland condition. Journal of soil and Crops. 10 (10): 109-113. 


\section{How to cite this article:}

Khumdemo Ezung, N. and Tiatula Jamir. 2019. Study on Growth and Yield of Upland Terrace Rice as Affected by Different Levels of Nitrogen and Spacing in Kiphire District, Nagaland of NE India. Int.J.Curr.Microbiol.App.Sci. 8(07): 467-474. doi: https://doi.org/10.20546/ijcmas.2019.807.057 